\title{
Peran Konselor dalam Pendidikan Karakter
}

\section{Rifda El Fiah}

Dosen Fakultas Tarbiyah dan Keguruan, IAIN Raden Intan Lampung

Diterima: April 2014. Disetujui: Mei 2014. Dipublikasikan: Juni 2014

\begin{abstract}
Abstrak: Pendidikan karakter merupakan salah satu fokus dalam sistem pendidikan nasional. Karena itu, pendidik tidak boleh mengabaikan hal ini. Seorang konselor sekolah, sebagai salah satu pendidik, harus berperan dalam pendidikan karakter. Mengacu pada tanggung jawab bimbingan dan konseling dalam kaitannya dengan aspek pribadi, sosial, akademik, dan karir siswa, seorang konselor sekolah tidak boleh lepas dari tugas pokoknya. Menimbang bahwa pendidikan karakter adalah tanggung jawab semua pihak, konselor sekolah dapat mandiri dan bekerja sama dengan semua komponen sekolah, berperan dalam pendidikan karakter. Secara individu, seorang konselor sekolah dapat memberikan layanan, seperti layanan individual, layanan perencanaan individual, dan layanan responsif. Berkolaborasi dengan pihak lain, seorang konselor sekolah bisa bersinergi dalam program pendidikan karakter
\end{abstract}

Kata Kunci: konselor sekolah, pendidikan karakter

\section{Pendahuluan}

Berbicara tentang bimbingan dan konseling (BK) tidak bisa terlepas dari pendidikan, karena bimbingan dan konseling ada di dalam pendidikan. Pendidikan bertolak dari hakikat manusia dan merupakan upaya membantu manusia dari kondisi obyektif apa adanya (what it is) kepada kondisi bagaimana seharusnya (what should be) (Kartadinata, 2010). Hal ini menggambarkan bahwa pendidikan merupakan aset yang tak ternilai bagi individu dan masyarakat. Namun perlu digarisbawahi bahwa pendidikan tidak bisa diukur atau dideskripsikan hanya dari megahnya gedung, fasilitas yang dimiliki atau banyaknya siswa, dan banyaknya personel yang mengelola; karena pendidikan lebih dari itu semua. Pendidikan adalah persoalan fokus dan tujuan. Ia merupakan proses yang esensial dalam mempengaruhi perkembangan manusia (Kartadinata, 2010).

Sebagai suatu proses pendidikan melibatkan berbagai faktor dalam mencapai kehidupan yang bermakna. Karena itu dikatakan mendidik adalah pilihan moral dan bukan pilihan teknis belaka. Menurut Terdapat tiga fungsi pendidikan, yakni (a) fungsi pengembangan, membantu individu mengembangkan diri sesuai dengan segenap potensi dan keunikannya; (b) fungsi peragaman (diferensiasi), membantu individu memilih arah perkembangan yang tepat sesuai dengan potensinya; dan (c) fungsi integratif, membawa keragaman perkembangan ke arah tujuan yang sama sesuai dengan hakikat manusia utnuk menjadi pribadi utuh (kaffah) (Kartadinata, 2010). Fungsi yang terakhir ini bermakna bahwa pendidikan berupaya mengintegrasikan nilai-nilai sosial budaya ke dalam kehidupan peserta didik baik yang menyangkut tatakrama, solidaritas, toleransi, kooperasi maupun empati sehingga peserta didik dapat belajar hidup bermasyarakat secara harmonis.

Untuk mewujudkan pendidikan yang bermutu diharuskan mengintegrasikan tiga bidang kegiatan utamanya yaitu bidang administratif dan kepemimpinan, bidang instruksional dan kurikuler dan bidang pembinaan siswa (bimbingan dan konseling yang memandirikan). Pendidikan yang hanya melaksanakan bidang administratif dan pengajaran dengan mengabaikan bidang bimbingan mungkin hanya akan menghasilkan individu yang pintar dan terampil dalam aspek akademik, namun kurang memiliki kemampuan atau kematangan dalam aspek psikososiospiritual (Natawidjaja, 1998, Yusuf dan Nurihsan, 2005). Jadi bimbingan dan konseling diperlukan dan merupakan bagian penting dalam upaya pencapaian tujuan pendidikan nasional. 
Secara formal Bimbingan dan konseling di Indonesia berada dalam institusi sekolah sejak tahun 1975, ketika diberlakukannya kurikulum 1975 di semua sekolah di seluruh penjuru tanah air. Hal ini bermakna bahwa sejak saat itu profesi BK di mulai diakui eksistensinya. Suatu profesi yang bertujuan membantu dan mendukung mengembangkan seluruh potensi dan kompetensi peserta didik sesuai dengan bakat, minat, dan kebutuhannya melalui layanan BK yang bersifat psikopedagogis. Dengan demikian, layanan BK di institusi pendidikan adalah salah satu bentuk kegiatan pendidikan guna mendukung tercapainya tujuan pendidikan. Dalam kaitan ini setumpuk harapan diembankan kepada para penyelenggara layanan BK di sekolah.

Di dalam mengemban misi mulya tersebut, BK sebagai suatu profesi yang secara legal formal relatif masih muda, banyak mengalami gangguan dan hambatan. Serangkaian gangguan dan hambatan dimaksud dapat dideteksi mulai dari jumlah sumber daya manusia (SDM) yang masih sangat terbatas hingga implementasi layanan BK yang belum optimal. Dampak dari rangkaian gangguan dan hambatan tersebut adalah gaung negatif yang menggambarkan bahwa konselor sekolah (guru pembimbing) masih sering diasumsikan secara keliru, misalnya konselor sebagai polisi sekolah, hanya memberikan nasehat, sosok yang menakutkan, atau cuma menangani siswa maladaptif. Miskonsepsi, ragam pemaknaan, dan pemahaman terhadap konselor seperti tersebut, akan memperhadapkan konselor kepada konflik, ketidakkonsistenan, dan ketidakkongruenan peran. Di samping itu konselor tentunya sangat sulit untuk dapat menuaikan tugas secara umum layanan BK bimbingan dan konseling dengan baik dan komprehensif, terlebih untuk melaksanakan pendidikan karakter. Dalam menanamkan karakter kepada peserta didik akan lebih mudah dan diharapkan menuai hasil yang baik bila konselor memiliki kedekatan personal dengan peserta didik, sehingga konselor gampang dijadikan model dan layak untuk dicontoh. Lumrahnya peserta didik didik akan 'respek' kepada konselor yang memiliki kedekatan secara pribadi sehingga memudahkan terjadinya penyampaian pesanpesan atau informasi tentang pendidikan karakter.

Tulisan ini mencoba menjadi wahana wacana bagaimana konselor harus menunjukkan tugas dan peran yang seharusnya dikerjakan sebagai seorang konselor, bagaimana konselor mengatasi adanya miskonsepsi, ragam pemaknaan, dan pemahaman terhadap profesinya dan pentingnya solusi untuk mengatasi keadaan tersebut. Walaupun terkesan sulit karena kondisinya, namun konselor harus mampu menunjukkan kinerjanya sehingga peserta didik yang dibantunya tidak lagi memperlihatkan perilaku negatif dan salah suai seperti berbohong, berkelahi, membolos, bersikap tidak sopan ataupun berperilaku melanggar norma-norma agama dan budaya.

Bagaimanapun sebagai seorang pendidik dan pembimbing, konselor harus mampu mengembangkan aspek pribadi dan aspek sosial peserta didik sehingga peserta didik memiliki kemampuan intrapersonal dan interpersonal yang baik. Tentunya pekerjaan mulia ini tidak akanmencapai hasil yang maksimal tanpa adanya kerjasama dengan pihak-pihak yang juga bertanggung jawab dalampendidikan karakter. Dengan kata lain walaupun konselor di sekolah bukan sebagai satu-satunya pihak yang harus atau paling bertanggung jawab terhadap penanaman karakter peserta didik, namun konselor di sekolah tidak bisa lepas dari tanggung jawab tersebut (Washington, Clark, \& Dixon, 2008). Dari konteks inilah diharapkan tulisan ini dapat memberikan sumbangan pemikiran guna mengurai kekusutan peran yang harus ditampilkan oleh konselor dalam pendidikan karakter di sekolah. Sehingga melalui pendidikan karakter, dunia pendidikan tak hanya menghasilkan manusia cerdas dan memiliki keterampilan, tapi juga memiliki integritas dan profesionalitas. 


\section{Metode Penelitian}

Metode penelitian ini dilakukan dengan deskriptif kualitatif dalam tulisan ini peneliti menggunakan studi pustaka atau menggali data dari library research untuk memperkaya khasanah keilmuan bimbingan dan konseling.

\section{Hasil dan Pembahasan}

Menurut Pusat Bahasa Depdiknas pengertian karakter adalah "bawaan, hati, jiwa, kepribadian, budi pekerti, perilaku, personality, sifat, tabiat, temperamen, watak". Adapun berkarakter adalah "berkepribadian, berperilaku, bersifat, bertabiat, dan berwatak". Menurut Tadkirrotun Musfiroh (UNY, 2008) karakter mengacu kepada serangkaian sikap (attitudes), perilaku (behavior), motivasi (motivation) dan keterampilan (skills). Karakter berasal dari bahasa Yunani yang berarti "to mark" atau menandai dan memfokuskan bagaimana mengaplikasikan nilai-nilai kebaikan dalam bentuk tindakan atau tingkah laku. Sehingga orang yang tidak jujur, kejam, rakus, sombong, pemarah, dan perilaku jelek lainnyadikatakan orang yang berkarakter jelek. Sebaliknya orang yang perilakunya sesuai dengan kaidah moral dan akhlak disebut berkarakter mulia (berakhlak mulia).

Pendidikan karakter sebagai "Any deliberate approach by which school personnel, often in conjunction with parents and community members, help children and youth become caring, principled and responsible". (Williams \& Schnaps, 1999) Maksudnya pendidikan karakter merupakan berbagai usaha baik yang dilakukan oleh para personil sekolah, maupun yang dilakukan bersama-sama dengan orang tua dan anggota masyarakat, untuk membantu anakanak dan remaja agar menjadi atau memiliki sifat peduli, berpendirian, dan bertanggung jawab. (Williams, 2000) lebih jauh menandaskan bahwa makna dari istilah pendidikan karakter dimaksud pada mulanya dipakai oleh National Commission on Character Education (Amerika) sebagai suatu istilah yang meliputi berbagai pendekatan, filosofi, dan program.

Serangkaian aspek seperti pemecahan masalah, pembuatan keputusan, penyelesaian konflik merupakan hal terpenting dari pengembangan karakter moral yang harus ditanamkan. Oleh sebab itu, di dalam upaya pendidikan karakter ini hendaklah memberikan kesempatan kepada siswa untuk mengalami langsung aspek-aspek tersebut secara langsung. Tujuan moral education adalah menolong peserta didik supaya secara moral lebih menjadi pribadi yang bertanggung jawab dan menjadi warga negara yang lebih berdisiplin (McBrien \& Brandt, 1997).

Selain itu dalam nuansa bimbingan dan konseling American School Counselor Association (ASCA, 1998) menghendaki arah tujuan pendidikan karakter sebagai "assist students in becoming positive and self-directed in their lives and education and in striving toward future goals", yakni membantu peserta didik untuk untuk menjadi lebih positif dan mampu mengarahkan diri dalam pendidikan dan kehidupan, dan berusaha keras dalam menggapai masa depannya. Sebuah harapan indah yang perlu diraih dengan mengajarkan kepada anak didik untuk menjadi individu yang senantiasa dapat dipercaya, rasa hormat dan perhatian, peduli, jujur, tanggung jawab, kewarganegaraan, ketulusan, berani, tekun, disiplin, visioner, adil, dan punya integritas (bandingkan dengan sifat Rasulullah SAW).

Secara historis, karakter ke- Indonesia-an itu terakumulasi dalam empat pilar kehidupan bangsa Indonesia, yang telah dirumuskan oleh para founding fathers. Empat pilar tersebut adalah Pancasila sebagai dasar dan falsafah hidup bangsa, Undang- Undang Dasar 1945 sebagai landasan konstusional, Bhinneka Tunggal Ika sebagai komitmen persatuan bangsa dan Negara Kesatuan Republik Indonesia sebagai rumah bersama bangsa Indonesia. Pancasila sebagai dasar dan falsafah hidup memuat lima prinsip moral dan etika kehidupan bangsa. Pertama, prinsip yang menegaskan bahwa, bangsa Indonesia adalah bangsa yang religius, ber Ketuhanan Yang Maha Esa, yang menjunjung tinggi nilai moralitas agama dengan saling 
menghargai agama dan keyakinan masing-masing warga negara. Kedua, prinsip menjunjung tinggi nilai-nilai kemanusiaan, keadilan dan keberadaban. Ketiga, prinsip menjunjung semangat persatuan dan kesatuan, semangat gotong royong dan kebersamaan dalam menghadapi dan mengatasi setiap masalah. Keempat, menjunjung tinggi semangat untuk musyawarah dan mufakat dalam menyelesaikan permasalahan bangsa. Kelima, prinsip perjuangan untuk mewujudkan keadilan sosial bagi seluruh rakyat Indonesia.

Syaiful Anwar (2011) menandaskan bahwa dalam pembukaan Undang-Undang Dasar 1945 ditegaskan tentang cita-cita perjuangan meraih kemerdekaan, bahwa" Atas berkat rakhmat Allah Yang Maha Kuasa dan dengan didorongkan oleh keinginan luhur supaya berkehidupan kebangsaan yang bebas maka rakyat Indonesia menyatakan dengan ini kemerdekaannya". Sementara, dalam semboyan Bhinneka Tunggal Ika, terkandung prinsip pengakuan terhadap keanekaan budaya, bahasa, adat, agama dan tradisi lokal yang tersebar dalam bentangan wilayah nusantara. Dalam prinsip ini sekaligus terkandung penegasan bahwa setiap usaha penyeragaman budaya bangsa Indonesia akan merusak karakter ke- Indonesiaan itu sendiri. Sebaliknya, yang harus dibangun adalah bagaimana kebersamaan dan persatuan masyarakat bangsa ini dapat terpelihara dengan kokoh tanpa mengurangi sedikitpun eksistensi masing-masing etnik serta kearifan-kearifan lokal yang terkandung di dalamnya.

Oleh karena itu perlu adanya satu kesatuan cara pandang terhadap keutuhan lingkungan wilayah negara ini, yang disebut dengan Wawasan Nusantara. Wawasan Nusantara sebagai cara pandang bangsa Indonesia tentang diri dan lingkungannya yang serba Nusantara dalam dunia yang serba berubah, namun tetap kokoh dalam nilai-nilai ke Indonesiaannya.

Wawasan ini telah memberi arah perilaku bangsa ini sebagai bangsa yang dinamis namun tetap kokoh dalam jati dirinya. Sementara, kesepakatan nasional yang telah menjadi warisan dari para founding fathers tentang rumah bersama masyarakat Indonesia adalah Negara Kesatuan Republik Indonesia (NKRI), bukan negara serikat. Otonomi Daerah tidak sedikitpun mengurangi nilai dasar dan makna NKRI. Oleh karena itu semangat kedaerahan yang bermuatan kearifan lokal patut dipelihara dan dikembangkan, sedang primordialisme yang bertentangan dengan semangat NKRI harus dijauhkan bahkan dimusnahkan.

Dalam konteks ini yang perlu digarisbawahi adalah bahwa dalam perjuangan mewujudkan kemerdekaan sekaligus merumuskan nilai-nilai luhur dan fundamental yang terkandung dalam empat pilar kehidupan bangsa Indonesia tersebut, para pendidik termasuk konselor memiliki andil dan peran yang besar. Oleh karena itu maka sesungguhnya lembaga sekolah dan personelnya, baik kepala sekolah, guru, maupun konselor mempunyai tanggung jawab moral dalam memelihara dan memperkokoh pendidikan karakter peserta didik di sekolah karena sesungguhnya pendidikan karakter itu, menjadi tugas dari semua pihak yang terlibat dalam upaya pendidikan.

Diamanatkan Undang-Undang No.20 Tahun 2003 tentang Sistem Pendidikan Nasional Pasal 3 bahwa "Pendidikan Nasional berfungsi mengembangkan kemampuan dan membentuk watak serta peradaban bangsa yang bermartabat dalam rangka mencerdaskan kehidupan bangsa, bertujuan untuk berkembangnya potensi peserta didik agar menjadi manusia yang beriman dan bertakwa kepada Tuhan Yang Maha Esa, berakhlak mulia, sehat, berilmu, cakap, kreatif, mandiri, dan menjadi warga Negara yang demokratis serta bertanggung jawab".

Amanat tersebut memperlihatkan bahwa pendidikan selain berfungsi sebagai media untuk mengembangkan kemampuan keilmuan, juga berfungsi untuk membentuk watak dan peradaban bangsa yang bermatabat. Hal ini bermakna sesungguhnya pendidikan watak/karakter tidak bisa ditinggalkan dalam berfungsinya pendidikan. Oleh karena itu, sebagai fungsi yang melekat pada keberadaan pendidikan nasional untuk membentuk watak dan peradaban bangsa, pendidikan karakter merupakan manifestasi dari peran dimaksud.

Sementara itu, di dalam Undang- Undang Sistem Pendidikan Nasional Tahun 2003 konselor di sekolah telah diakui sebagai salah satu tenaga pendidik, seperti yang tersurat di 
dalam Pasal 1, "Pendidik adalah tenaga kependidikan yang berkualifikasi sebagai guru, dosen, konselor, pamong belajar, widyaiswara, tutor, instruktur, fasilitator, dan sebutan lain yang sesuai dengan kekhususannya, serta berpartisipasi dalam menyelenggarakan pendidikan”. Dari pengertian tersebut maka konselor di sekolah, menurut Surat Keputusan Bersama Menteri Pendidikan dan Kebudayaan dan Kepala Badan Administrasi Kepegawaian Nasional Nomor 25 Tahun 1993) tidak bisa lepas dari fungsi dan tujuan pendidikan tersebut. Konselor di sekolah mempunyai peran dan tugas yang terkait dengan pendidikan karakter. (Stone \& Dyal, 1997) Sebagai salah satu pihak yang berkepentingan dengan ini, konselor sekolah harus berkomitmen untuk melaksanakan pendidikan karakter tersebut.

Berdasarkan pemahaman tentang karakter bangsa Indonesia seperti diuraikan di atas, maka dapat diperoleh gambaran tentang betapa penting dan proporsionalnya topik bahasan "Peran Konselor Dalam Pendidikan Karakter", ini. Misi yang diemban konselor adalah membimbing anak didik untuk menjadi insan yang beriman dan bertakwa sehingga muaranya adalah terciptanya situasi dan kondisi masyarakat yang sejahtera, masyarakat dalam kehidupan di alam semesta yang rahmatan lil alamin. Keberhasilan dalam menyelenggarakan dan menanamkan nilai-nilai kehidupan melalui pendidikan karakter dapat pula dipengaruhi oleh pendekatan dan metode yang dipergunakan dalam menyampaikan. Ada empat pendekatan penyampaian pendidikan karakter (Suparno, Paul, K., Titisari, \& Kartono., 2002). Berikut adalah pendekatan- pendekatan yang dimaksud.

\section{Pendekatan Mata Pelajaran Tersendiri}

Dalam pendekatan ini, pendidikan karakter dianggap sebagai mata pelajaran tersendiri. Oleh karena itu, pendidikan karakter memiliki kedudukan yang sama dan diperlakukan sama seperti pelajaran atau bidang studi lain. Dalam hal ini, guru bidang studi pendidikan karakter seyogyanya mempersiapkan dan mengembangkan kurikulum, mengembangkan silabus, membuat Rancangan Proses Pembelajaran (RPP), metodologi pembelajaran, dan evaluasi pembelajaran. Konsekuensinya pendidikan karakter harus dirancangkan dalam jadwal pelajaran secara terstruktur. Pendekatan ini memiliki kelebihan dan kekurangan. Kelebihan dari pendekatan ini antara lain materi yang disampaikan menjadi lebih terencana matang dan terfokus; demikian juga materi yang telah disampaikan lebih terukur. Sedangkan kelemahannya adalah sangat tergantung pada tuntutan kurikulum, demikian pula dampak yang muncul pendidikan karakter hanya menyentuh aspek kognitif dan tidak menyentuh internalisasi nilai tersebut. Padahal hal yang paling penting dari pendidikan karakter adalah internalisasi nilai-nilai dalam kepribadian peserta didik. Di samping itu penanaman nilainilai tersebut seolah-olah hanya menjadi tanggung jawab satu orang guru semata. Untuk mengatasi kelemahan tersebut dapat dipakai pendekatan kedua, yaitu mengintegrasikan dengan semua mata pelajaran.

2. Pendekatan Terintegrasi dalam Semua Bidang

Studi Pendekatan ini adalah dengan menyampaikan pendidikan karakter adalah lebih variatif, yaitu dengan melaksanakannya secara terintegrasi dalam setiap bidang pelajaran. Oleh karena itu pendidikan karakter tidak terbebankan pada pundak seorang guru saja namun menjadi tanggung jawab semua guru (Washington, et.all, 2008). Dalam konteks ini setiap guru dapat memilih materi pendidikan karakter yang sesuai dengan tema atau pokok bahasan bidang studi. Melalui model terintegrasi ini maka setiap guru adalah pengajar pendidikan karakter tanpa kecuali. Keunggulan model terintegrasi pada setiap bidang studi

antara lain setiap guru ikut bertanggung jawab akan penanaman nilai-nilai hidup kepada semua siswa, di samping itu pemahaman akan nilai-nilai pendidikan karakter cenderung tidak bersifat informatif-kognitif, melainkan bersifat aplikatif sesuai dengan konteks pada setiap bidang studi. Dampaknya siswa akan lebih terbiasa dengan nilai- nilai yang sudah diterapkan dalam berbagai seting. Sisi kelemahannya adalah pemahaman dan persepsi tentang nilai yang akan ditanamkan harus jelas dan sama bagi semua guru. Namun, 
menjamin kesamaan bagi setiap guru adalah hal yang tidak mudah, hal ini mengingat latar belakang setiap guru yang berbeda-beda. Di samping itu, jika terjadi perbedaan penafsiran nilai-nilai di antara guru sendiri akan menjadikan anak didik justru menjadi kabur bahkan membingungkan mereka.

3. Model di Luar Pengajaran

Penanaman nilai-nilai pendidikan karakter dapat juga ditanamkan di luar kegiatan pembelajaran formal. Pendekatan ini lebih mengutamakan pengolahan dan penanaman nilai melalui suatu kegiatan untuk dibahas dan kemudian dibahas nilai-nilai hidupnya. Model kegiatan demikian dapat dilaksanakan oleh guru sekolah yang diberi tugas tersebut atau dipercayakan kepada lembaga lain untuk melaksanakannya. Kelebihan pendekatan ini adalah siswa akan mendapatkan pengalaman secara langsung dan konkrit. Kelemahannya adalah tidak ada dalam struktur yang tetap dalam kerangka pendidikan dan pengajaran di sekolah, sehingga akan membutuhkan waktu yang lebih lama dan biaya yang lebih banyak.

4. Model Gabungan

Model gabungan adalah menggabungkan antara model terintegrasi dan model di luar pelajaran secara bersama. Model ini dapat dilaksanakan dalam kerja sama dengan tim baik oleh guru maupun dalam kerja sama dengan pihak luar sekolah. Kelebihan model ini adalah semua guru terlibat, di samping itu guru dapat belajar dari pihak luar untuk mengembangkan diri dan siswa. Siswa menerima informasi tentang nilai-nilai sekaligus juga diperkuat dengan pengalaman melalui kegiatan-kegiatan yang terencana dengan baik. Mengingat pendidikan karakter merupakan salah satu fungsi dari pendidikan nasional, maka sepatutnya pendidikan karakter ada pada setiap materi pelajaran.

Oleh karena itu, pendekatan secara terintegrasi merupakan pendekatan minimal yang harus dilaksanakan semua tenaga pendidik sesuai dengan konteks tugas masing-masing di sekolah, termasuk dalam hal ini adalah konselor sekolah. Namun, bukan berarti bahwa pendekatan yang paling sesuai adalah dengan model integratif. Pendekatan gabungan tentu akan lebih baik lagi karena siswa bukan hanya mendapatkan informasi semata melainkan juga siswa menggali nilai-nilai pendidikan karakter melalui kegiatan secara kontekstual sehingga penghayatan siswa lebih mendalam dan tentu saja lebih menggembirakan siswa. Dari perspektif ini maka konselor sekolah dituntut untuk dapat menyampaikan informasi serta mengajak dan memberikan penghayatan secara langsung tentang berbagai informasi nilai-nilai karakter.

Dalam proses pendidikan karakter di sekolah konselor sekolah hendaklah menjadi fasilitator pengembangan dan penumbuhan karakter tanpa mengabaikan penguasaan hard skills yang diperlukan dalam perjalanan hidup serta dalam mempersiapkan karier (Nasional, 2007) Oleh karena itu, konselor sekolah hendaknya merancangkan dalam program kegiatannya untuk secara aktif berpartisipasi dalam pengembangan dan penumbuhan karekter pada siswa. Kegiatan tersebut dapat dilakukan secara mandiri yang terancang dalam program bimbingan dan konseling, dan juga bersama-sama dengan pendidik lain (guru bidang studi misalnya) yang terancang dalam program sekolah yang dilakukan secara sinergis dari beberapa pihak. Di dalam buku Rambu-rambu Penyelenggaraan Bimbingan dan Konseling dalam Jalur Pendidikan Formal, di dalam lampiran 3 Standar Kompetensi Konselor (Depdiknas, 2007:261) dijelaskan bahwa layanan ahli BK yang diasuh oleh konselor sekolah berada dalam konteks tugas "kawasan pelayanan yang bertujuan memandirikan siswa (individu) dalam menavigasi perjalanan hidup siswa melalui pengambilan keputusan tentang pendidikan termasuk yang terkait dengan keperluan untuk memilih, meraih serta mempertahankan karier untuk mewujudkan kehidupan yang produktif dan sejahtera, serta untuk menjadi warga masyarakat yang peduli kemaslahatan umum melalui pendidikan". Motif altruistik dalam arti selalu menggunakan penyikapan yang empatik, menghormati keragaman, serta mengedepankan kemaslahatan pengguna pelayanannya, dilakukan dengan selalu mencermati kemungkinan 
dampak jangka panjang dari tindak pelayanannya terhadap pengguna pelayanan merupakan ekspektasi kinerja konselor yang mengampu pelayanan bimbingan dan konseling, sehingga disebut "the reflective practitioner".

Dalam konteks kegiatan tersebut, maka layanan yang diberikan oleh konselor sekolah dapat bersifat preventif, kuratif, dan developmental dalam rangka menunjang fungsi pendidikan dalam mengembangkan karakter peserta didik. Bersifat preventif berarti kegiatan layanan yang dilakukan oleh konselor bermaksud untuk mencegah agar perilaku konseli tidak berlawanan dengan nilai-nilai karakter yang diharapkan. Bersifat kuratif berarti bahwa layanan konselor ditujukan untuk mengobati/memperbaiki perilaku konseli yang sudah terlanjur melanggar nilai-nilai karakter yang diharapkan. Bersifat developmental bermakna layanan yang diberikan oleh konselor bertujuan untuk memelihara dan sekaligus mengembangkan perilaku konseli yang sudah tepat agar tetap terjaga dengan baik, tidak melanggar norma dan nilai-nilai yang ada, dan juga mengembangkan agar semakin lebih baik lagi perkembangan karakternya.

Materi pendidikan karakter begitu luas cakupannya bahkan nyaris menjangkau semua lini kehidupan manusia (Berkowitz, 2008). Lebih jauh Berkowitz dkk. Mengemukakan bahwa minimal terdapat 25 variabel yang dapat digunakan dan dimanfaatkan menjadi jabaran materi pendidikan karakter. Tetapi mereka menjelaskan bahwa dari 25 variabel dimaksud yang diungkapkan dan cukup signifikan hanya10, yaitu: Perilaku seksual, Pengetahuan tentang karakter (character knowledge), Pemahaman tentang moral sosial, Keterampilan pemecahan masalah, Kompetensi emosional, Hubungan dengan orang lain (relationships), Perasaan keterikatan dengan sekolah (Attachment to school), Prestasi akademis, Kompetensi berkomunikasi, Sikap kepada guru (attitudes toward teachers).

Sementara itu, gaung pendidikan karakter yang diintegrasikan ke dalam seluruh masyarakat sekolah sebagai suatu strategi untuk membantu mengingatkan kembali siswa untuk berhubungan dengan konflik, menaungi siswa untuk tetap selalu siaga dalam lingkungan edukatif, dan menginvestasikan kembali masyarakat untuk berpartisipasi aktif sebagai warga Negara (citizenship). Di dalam situsnya ERIC Resource Center (www.-eric.ed.gov) lebih jauh menjelaskan bahwa bahwa dengan semakin meningkatnya urgensi pendidikan karakter, maka konselor sekolah dituntut untuk memahami tentang berbagai cara dan teknik menggabungkan pendidikan karakter dalam layanan program bimbingan dan

konseling. (Otten, 2000) Untuk kasus sekolah di tanah air materi ini kemudian banyak disebut sebagai pengembangan diri. Adapun jenis materi yang disarankan untuk diterapkan oleh konselor antara lain sebagai berikut.

1. Tanggung Jawab (Responsibility), yaitu berupa kemampuan untuk mempertanggungjawabkan. Peserta didik dibekali agar memiliki perasaan untuk menunaikan tugas yang dibebankan kepadanya dengan rasa dapat dipercaya, mandiri dan berkomitmen, baik terhadap diri sendiri, orang lain, maupun Tuhannya.

2. Ketekunan (Perseverance), kemampuan mencapai sesuatu dengan menentukan nilai-nilai obyektif disertai kesabaran dan keberanian di saat menghadapi kegagalan. Peserta didik diajak untuk tidak cepat merasa puas jika berhasil atau cepat berputus asa bila menemui hal yang tidak sesuai antara harapan dan kenyataan.

3. Kepedulian (Caring), kemampuan menunjukkan pemahaman terhadap orang lain dengan memperlakukannya secara baik, dengan belas kasih, bersikap dermawan, dan dengan semangat memaafkan. Peserta didik diajarkan untuk mampu memiliki sikap empati terhadap sesama maupun lingkungannya.

4. Disiplin (Sef-Discipline), kemampuan menunjukkan hal yang terbaik dalam segala situasi melalui pengontrolan emosi, kata-kata, dorongan, keinginan, dan tindakan. Peserta didik diberi pemahaman bahwa segala sesuatu yang dikerjakannya menuntut disiplin dari dan 
tidak tergopoh-gopoh atau pun terkesan lamban menghadapi setiap kondisi dalam kehidupannya.

5. Kewarganegaraan (Citizenship), kemampuan untuk mematuhi hukum dan terlibat dalam pelayanan kepada sekolah, masyarakat dan Negara sesuai dengan kapasitasnya sebagai warga terdidik dan masyarakat edukatif.

6. Kejujuran (Honesty), kemampuan menyampaikan kebenaran, mengakui kesalahan, dapat dipercaya, dan bertindak secara terhormat. Peserta dididik dibekali kompetensi untuk bersikap dan bertindak konsisten antara ucapan dan perilaku, tidak mudah menyalahkan pihak lain apalagi sampai merugikan orang lain karena ketidakkonsistenannya.

7. Keberanian (Courage), bertindak secara benar pada saat menghadapi kesulitan dan mengikuti hati nurani dari pada pendapat orang banyak. Peserta didik dibekali kemampuan untuk berani tampil beda demi sebuah kebenaran dan tidak asal bapak senang (ABS).

8. Keadilan (Fairness), melaksanakan keadilan sosial, kewajaran dan persamaan. Bekerja sama dengan orang lain. Memahami keunikan dan nilai-nilai dari setiap individu di dalam masyarakat. Peserta didik mengakui bahwa Tuhan memang menciptakan dunia ini penuh warna dan perbedaan agar lebih indah dan saling melengkapi menuju kesempurnaan.

9. Rasa Hormat (Respect), peserta didik memperlihatkankan rasa hormat yang tinggi atas kewibawaan orang lain, diri sendiri, dan negara. Ancaman kepada orang lain diterima sebagai ancaman juga kepada diri sendiri dan tidak bersikap masa bodoh terhadap lingkungan. Memahami bahwa semua orang memiliki nilia-nilai kemanusiaan yang sama (universal).

10. Integritas (Integrity), peserta didik benar-benar memiliki suatu ketegasan di dalam menaati suatu nilai- nilai moral, budaya dan agama, sehingga menjadi jujur, dapat dipercaya, dan penuh kehormatan sebagai diri sendiri dan makhluk Tuhan yang terbaik dibanding makhluk lainnya berangkat dari penjabaran di atas, maka materi-materi tersebut memang banyak terkait dengan bidang layanan bimbingan dan konseling, khususnya bimbingan pribadi dan bimbingan sosial. Oleh karena itu, ketersediaan materi pendidikan karakter bagi konselor sekolah di Indonesia begitu luas dan beragam. Nilai-nilai esensi moralitas baik sebagai makhluk individu dan atau sebagai makhluk sosial bagi seorang peserta didik merupakan materi pendidikan moral dan pendidikan karakter.

Di jelaskan dalam ERIC Resource Center (www.eric.ed.gov) bahwa bila pendidikan karakter diselenggarakan di sekolah, maka yang menjadi pioner dan sekaligus koordinator program tersebut adalah konselor sekolah. Hal ini dimungkinkan karena kanselor sekolah yang memang secara khusus memiliki tugas untuk membantu peserta didik mengembangkan rasa kepedulian sosial dan masalah-masalah kesehatan mental. Pernyataan ini menggambarkan bagaimana harus dekat dan akrabnya konselor sekolah dengan program pendidikan karakter. Gambaran ini dapat dimengerti karena sejatinya fungsi konselor sekolah memang sangat berkaitan dengan watak dan karakter peserta didik. Tugas utamanya membuat peserta didik menjadi individu yang mandiri dan bertanggung jawab. Berkaitan dengan pentingnya peran konselor sekolah dalam pendidikan karakter ini American School Counselor Association (ASCA) menunjukkan dukungannya dengan menyatakan:

"Professional school counselors need to take an active role in initiating, facilitating and promoting character education programs in the school curriculum.The professional school counselor, as a part of the school community and as a highly resourceful person, takes an active role by working cooperatively with the teachers and administration in providing character education in the schools as an integral part of the school curriculum and activities" (ASCA, 1998).

Pernyataan di atas sesungguhnya menyiratkan perlunya konselor sekolah untuk senantiasa diperingatkan agar mereka memahami dan menyadari salah satu tugas pokoknya. 
Hal itu harus benar-benar digarisbawahi karena hasil penelitian menunjukkan bahwa sebenarnya program bimbingan dan konseling di sekolah pada dasarnya juga sudah mengakomodasi materi tugas tersebut (Ryan \& Bohlin, 2000).

Namun demikian, tidak menutup kemungkinan ada pihak yang kurang bersepakat dengan pernyataan tadi bahkan merekomendasikan agar konselor sekolah hendaknya menjauhi pendidikan karakter karena terasa bertentangan dengan kebebasan akademis, atau bahkan menyalahi atau menyangkut keyakinan pribadi atau melanggar hak dan perilaku pribadi (Ryan \& Bohlin, 2000).

Dari sisi ini mereka menganggap bahwa masalah pribadi (seperti keyakinan dan agama) ataupun masalah karakter adalah hal-hal yang masih menjadi isu sentral dalam dunia bimbingan dan konseling. Sungguhpun begitu, konselor sekolah sebelumnya perlu memperhatikan dan mempertimbangkan bahwa semua bentuk pendidikan sejatinya pasti berisi materi tentang hal-hal yang senantiasa mengajarkan nilai-nilai kebaikan, kemanusiaan, dan kehidupan yang pada hakekatnya itu semua adalah pendidikan karakter.

Untuk memperkecil perbedaan pendapat di atas berikut ini ada sejumlah pertimbangan yang dapat diperhatikan bahwa konselor sekolah wajib berperan dalam pendidikan karakter di sekolah.

Ini merupakan tugas dan fungsi dasar dari setiap pendidik. Seperti dijelaskan di atas, konselor adalah salah satu jenis tenaga pendidik dari sejumlah pendidik lainnya. Sementara itu salah satu fungsi pendidikan nasional adalah mengembangkan watak dan karakter bangsa. Sementara itu, konselor adalah merupakan salah satu pendidik yang telah diakui sebagai tenaga kependidikan. Karenanya konselor sekolah sebagai representasi pendidik jelas memiliki rasional yang kuat untuk menyampaikan dan mengembangkan pendidikan karakter kepada anak didiknya. Dengan kata lain di pundak konselor sekolah pendidikan karakter sudah menjadi salah satu tugas dan kewajiban yang harus diemban dalam memberikan layanan bimbingan dan konseling, baik dilaksanakan secara langsung maupun tidak langsung. Secara langsung dimaksudkan konselor sekolah harus merencanakan dan merancangkan pelaksanaan pendidikan karakter dalam program kegiatan layanannya. Melalui program yang sudah direncanakan dan dirancangkan dapat dibuat serangkaian kegiatan untuk menyampaikan pesan-pesan pengembangan karakter peserta didik. Oleh karena itu, konselor sekolah seyogyanya memahami betul bagaimana metodenya memilih, menyampaikan, dan memfasilitasi program pendidikan watak ini. Secara tidak langsung dimaksudkan konselor sekolah dapat menyampaikan nilai-nilai pendidikan watak dan karakter di setiap ada kesempatan untuk menyampaikannya, artinya konselor sekolah berkewajiban menyelenggarkan dan menyampaikan di manapun dan kapanpun untuk melaksanakan tugasnya secara sadar atau ingat bahwa dirinya memiliki kewajiban untuk melaksanakan pendidikan karakter dengan cara mengintegrasikan dalam menunaikan tugasnya sebagai pendidik.

Konselor Sekolah sebagai Manajer Kegiatan Pendidikan karakter. Pernyataan di atas menggambarkan bahwa konselor sekolah sebagai manajer bermakna bahwa dirinya harus mampu mengelola seluruh kegiatan yang telah diprogramkan dan dirancangkan melalui keterlibatan berbagai pihak untuk pelaksanaan pendidikan karakter di sekolah. Konselor sekolah hendaknya mampu melibatkan semua pemangku kepentingan (siswa, guru bidang studi, kepala sekolah, maupun orang tua) untuk terlibat dan berupaya menyukseskan pelaksanaan program yang sudah dirancangkannya. Sejak dari program pelayanan dasar yang berupa rancangan kurikulum bimbingan yang berisi materi tentang pendidikan karakter, antara lain kerja sama, keberagaman, kejujuran, menangani kecemasan, membantu orang lain, persahabatan, ketekunan, kesungguhan, manajemen konflik, pencegahan penggunaan narkotika. 
Pelaksanaan program pelayanan dasar ini dipastikan sangat memerlukan keterlibatan (kooperatif) pihak lain. Hal ini sebagai wujud bahwa pendidikan karakter betul-betul merupakan tanggung jawab bersama sebagai pendidik dan keberhasilannya memerlukan kerja sama antar pihak yang merasa bertanggung jawab sebagai pendidik. Selain itu, masih ada program lain, yaitu program perencanaan individual berupa layanan untuk membantu membuat pilihan atau keputusan yang bertanggung jawab dari peserta didik, dan program pelayanan responsif yang antara lain berupa kegiatan konseling individu dan konseling kelompok. Tentunya kesuksesan semua rancangan pendidikan karakter yang sudah direncanakan konselor sekolah sangat memerlukan dukungan sistem.

Konselor Sekolah sebagai Konselor, Pernyataan di atas dimaksudkan bahwa sebagai pendidik yang melaksanakan fungsi sebagai pembimbing maka konselor sekolah tentunya melaksanakan fungsinya sebagai konselor yaitu antara lain menjalankan fungsi kuratif dalam menyelesaikan masalah peserta didik (konseli). Hal ini mengingat bahwa di sekolah setiap peserta didik tidaklah steril terhadap berbagai permasalahan kehidupan terutama sebagai makhluk individu dan makhluk sosial. Kemampuan untuk menerima kondisi diri sendiri sampai dengan masalah hubungan dengan orang lain sering menimbulkan dilema bagi para peserta didik. Kemampuan untuk memahami diri, menerima diri, dan mengarahkan diri memerlukan proses bantuan agar peserta didik terbiasa untuk mampu memilih dari berbagai alternatif dengan berbagai konsekuensi sehingga konseli semakin mandiri. Demikian pula kemampuan memahami orang lain, memaklumi orang lain, menerima orang lain, dan memperlakukan orang lain dengan baik dan benar memerlukan proses bantuan yang panjang agar setiap konseli mampu bersikap ramah, solider, toleran, empatik, dan sebagainya sehingga mereka jauh dari kesan bersikap arogan, kasar, sangar, kejam, dan sebagainya. Kondisi realita para peserta didik yang demikian mengharuskan konselor sekolah untuk menjadi sebenarbenarnya konselor untuk membantu mengatasi berbagai permasalahan yang mungkin timbul pada diri konseli. Serangkaian masalah yang muncul tersebut sebenarnya merupakan rangkaian masalah dalam perkembangan kepribadian dan watak peserta didik.

Dari perspektif ini pada dasarnya kegiatan konseling yang dilakukan oleh konselor sekolah untuk mengatasi bermacam masalah individu dan sosial konseli adalah inti pelaksanaan pendidikan karakter. Di sinilah begitu jelas fungsi konselor sekolah, dan ini menggambarkan tidak akan pernah ada alasan konselor sekolah menjauhi kegiatan pendidikan karakter. Dengan menjalankan fungsi inilah konselor sekolah dapat dikatakan telah menjalankan fungsi utamanya secara efektif.

Konselor Sekolah sebagai Konsultan Tidak ada perbedaannya dengan tugas sebagai konselor, berperan sebagai konsultan, konselor sekolah menerima konsultasi dari berbagai pihak lain untuk membantu perkembangan peserta didik. Pendidikan karakter memerlukan sikap kooperatif semua pihak sekolah maupun keluarga dan tidaklah mungkin diselesaikan sendiri oleh salah satu pihak. Ditilik dari sisi ini maka semua pihak memiliki peran yang bersifat saling komplementer. Oleh karena itu, konselor sekolah sebagai pihak yang memberikan layanan bersifat psikopedagogis harus mampu memberikan layanan yang bersifat konsultatif atas kepentingan berbagai pihak, mulai dari peserta didik, guru, orang tua, kepala sekolah, bahkan mungkin sampai dengan masyarakat.

Berangkat dari perspektif rasional tentang tugas konselor sekolah terkait dengan pendidikan karakter di Indonesia tersebut, maka berikut ini dapat diketahui sejumlah peran konselor sekolah dalam pelaksanaan pendidikan karakter di Indonesia.

Konselor Sekolah sebagai Perancang Kegiatan Suatu program akan mencapai hasil yang baik bila program tersebut dirancang dan dipersiapkan dengan baik. Demikian juga pelaksanaan pendidikan karakter. Konselor sekolah dapat membantu keberhasilan pelaksanaan pendidikan karakter dengan memprogramkan pendidikan karakter melalui rangkaian program pelayanan dasar BK berupa informasi yang yang beragam yang secara langsung (terintegrasi) 
dalam pelaksanaan kegiatan layanan bimbingan dan konseling, misalnya yang berkenaan dengan materi-materi layanan bimbingan pribadi dan bimbingan sosial. Materi layanan bimbingan pribadi antara lain kejujuran, ketekunan, tanggung jawab, keberanian, kedisiplinan, integritas, kompetensi emosional dan seterusnya, sedangkan bimbingan sosial antara lain meliputi keadilan, toleransi, rasa hormat, kompetensi penyelesaian masalah, keterampilan berkomunikasi, dan sebagainya. Dari berbagai materi tersebut, terlihat sekali bahwa konselor sekolah mempunyai peran yang sangat sentral dalam pelaksanaan pendidikan karakter di tanah air bila diprogramkan dalam kegiatan bimbingan dan konseling. Kegiatan ini tentunya dapat diaplikasikan secara mandiri ataupun bersama-sama dengan guru lain di sekolah.

Konselor Sekolah sebagai Healer/Problem Solver. Di samping berperan sebagai perancangan program kegiatan, konselor sekolah dapat juga berperan sebagai healer/problem solver dalam pendidikan karakter. Kenyataan di sekolah para siswa menghadapi berbagai masalah mulai dari masalah belajar, masalah karir, masalah pribadi, sampai masalah sosial. Seperti dijelaskan di atas bahwa pelayanan bimbingan dan konseling terkait dengan pendidikan karakter khususnya melalui bimbingan pribadi dan bimbingan sosial. Dalam perspektif ini maka peran konselor sekolah dapat diterapkan saat membantu memecahkan berbagai permasalahan yang terkait dengan masalah pribadi atau masalah sosial. Hal itu semua sebagai bentuk kegiatan pelayanan responsif dari konselor sekolah. Di samping itu, ketika siswa menghadapi berbagai persoalan yang bersifat pilihan maka peran konselor untuk membantu siswa memilih dapat dilakukan melalui kegiatan perencanaan individual.

Konselor Sekolah sebagai Konsultan/Mediator. Pendidikan karakter merupakan tugas dan tanggung jawab semua personil pendidik di sekolah tak terkecuali konselor. Karenanya, konselordapat memainkan perannya sebagai patner ataupun sebagai konsultan dalam pelaksanaan pendidikan watak ini di sekolah. Bahkan, konsulasi tidak terbatas hanya dengan para pelaksana pendidikan karakter di sekolah (guru, kepala sekolah) tetapi juga dengan para proses pendidikan karakter di luar sekolah (orang tua, anggota masyarakat). Hal ini sangat mungkin dilakukan mengingat pendidikan karakter sejatinya berkenaan dengan banyak pihak bahkan hamper semua pihak yang terlibat dalam pelaksanaanya. Selain itu di mungkinkan juga konselor sekolah bertindak sebagai mediator dalam rangka penyelesaian permasalahan yang dihadapi para siswa.

\section{Simpulan dan Saran}

Konselor sekolah mempunyai tugas yang sangat dekat dan erat dengan misi pendidikan karakter. Kedekatan dan keeratan kewajiban konselor sekolah terhadap pendidikan karakter terlihat secara jelas dari bidang gerak bimbingan dan konseling yang berimplikasi bahwa konselor sekolah secara substantif dan fungsional memiliki tugas yang tidak terelakkan. Oleh karena itu, konselor sekolah di Indonesia baik secara langsung maupun tidak langsung berkewajiban menyelenggarakan program pelayanan bimbingan dan konseling yang bernuansa nilai-nilai pendidikan karakter. Selain itu, konselor harus menyiapkan diri untuk melakukan koordinasi dan sinkronisasi sebagai bentuk sinergi pelaksanaan pendidikan karakter. Tidak ketinggalan, sebagai konselor hendaknya mengembangkan nilai-nilai pendidikan karakter melalui kegiatan konseling yang dilakukannya.

\section{Daftar Pustaka}

American School Counseling Association. 1998. American School Counseling Association's Position Statement on Character Education. http://www.schoolcounselor.org/cont ent.cfm?L1=1000\&L2=7. Diunduh 10 Desember 2010. 
ERIC Resource Center ED475389 2003-06-00 Character Education: What Counselor Educators Need ToKnow. ERIC/CASS Digest. www.eric.ed.gov. Diunduh 2 Maret 2010

ASCA. (1998). ASCA. Retrieved from https://www.schoolcounselor.org

Berkowitz, M. B. (2008). "What Works in Character Education: What Is Known and What Needs to Be Known". Handbook of Moral and Character Education, 414-431.

Dulewicz, V., \& Malcolm, H. (2000). Emotional Intelligence You can't Afford to Ignore It . Retrieved from ASE: http://www.ase-solutions.co.ak/ei/Default. htm

Gardner, H. (1993). Multiple Intelligences ; The Theory In Practice. New York: Basic.

Goleman, D. (2000). Emotional Intelligence (Terjemahan). Jakarta: Gramedia Pustaka Utama.

Kartadinata, S. (2010). Mencari Bentuk Pendidikan Karakter Bangsa. Retrieved from http://file. upi. edu/Direkt0ri/A

McBrien, J. L., \& Brandt, R. S. (1997). TheLanguage of Learning: A Guide to Education Terms. Alexandria: Association for Supervision and Curriculum Development.

Nasional, D. P. (2007). Penataan Pendidikan Profesional Konselor Dan Layanan Bimbingan dan Konseling dalam Jalur Pendidikan Formal. . Bandung: PPB FIP UPI.

Otten, E. H. (2000). "Character Education.Bloomington, IN: ERIC Clearinghouse for Social Studies/ Social Science Education”. . Retrieved from ERIC Document Reproduction Service: http://www.ed.gov/databases/ERIC_Digests/ed444932.html

Ryan, K., \& Bohlin, K. (2000). Teacher Education's EmptySuit. Education Week. Retrieved from http://www.edweek.org/ew/ewstory.cfm?slug=26ryan.h19

Salovey, P. B., \& Mayer, M. (2004). Emotional Intelligence. New York: National Professional Resources, Inc.

Stone, C., \& Dyal, M. (1997). "School Counselors Sowing the Seeds of Character Education”. Professional School Counseling, 22-24.

Suparno, Paul, K., M. Y., Titisari, D., \& Kartono. (2002). Pendidikan Budi Pekerti di Sekolah. . Yogyakarta: Kanisius.

Washington, E. Y., Clark, M., \& Dixon, A. (2008). "Everyone in School Should Be Involved" Preservice Counselors' Perceptions of Democracy and the Connections Between Character Education and Democratic Citizenship Education". Journal of Research in Character Education, 6(2), 63-80.

Williams, M. (2000). "Models of Character Education: Perspectives and Developmental Issues". Journal of Humanistic Counseling, Education and Development, 39, 32-40.

Williams, M., \& Schnaps, E. (1999). Character Education: The foundation for teacher Education. Washington, DC: Character Education Partnership. 